\title{
Non-classic Meigs-Like Syndrome
}

\section{Non-klasik Meigs' Benzeri Sendrom}

To the Editor,

A 22-year old woman presented to the chest diseases clinic with complaints of non-productive cough and left side chest pain, ongoing for two days. She had been admitted to the hospital with a sudden abdominal pain three days earlier. She was diagnosed with an abdominopelvic abscess with a ruptured dermoid cyst, and a salpingooopherectomy was performed. The left side chest pain initiated three days later.

Upon physical examination, vital signs were normal and room air oxygen saturation was $98 \%$. Respiratory sounds in the bilateral lower chest were decreased. An instant chest radiograph revealed blunt costophrenic angles suggestive of a bilateral pleural effusion (Figure 1).

Upon ED admission, biochemistry values were within normal limits, complete blood count parameters revealed a mild leukocytosis of $12.6 \mathrm{~K} / \mathrm{L}$, hemoglobin was decreased to $8.9 \mathrm{~g} / \mathrm{dl}$, and Creactive protein (CRP) was $154 \mathrm{mg} / \mathrm{L}$. On the day of the consultation, a complete blood count revealed leukocytosis of $9.6 \mathrm{~K} / \mathrm{L}$, hemoglobin of $10.1 \mathrm{~g} / \mathrm{dl}$ and CRP of $58 \mathrm{mg} / \mathrm{L}$. She had neither fever nor sputum. D-dimer was $812 \mathrm{ng} / \mathrm{mL}$.

Upon ED admission, no pleural effusion was seen at the proximal sections in an abdominal computer tomography (CT), although ascites and a minimal pericardial effusion were detected (Figure 2). The pleural fluid was exudative according to Light's criteria (1); the pleural fluid to serum ratio for protein was 0.62 (3.6 vs. $5.8 \mathrm{~g} / \mathrm{dl}$, respectively); and the pleural fluid to serum ratio for lactate dehydrogenase was 0.89 (197 vs. $219 \mathrm{U} / \mathrm{L}$, respectively). A cytological examination identified the usual pleural fluid cells, and no proliferation of microbiologic agents.

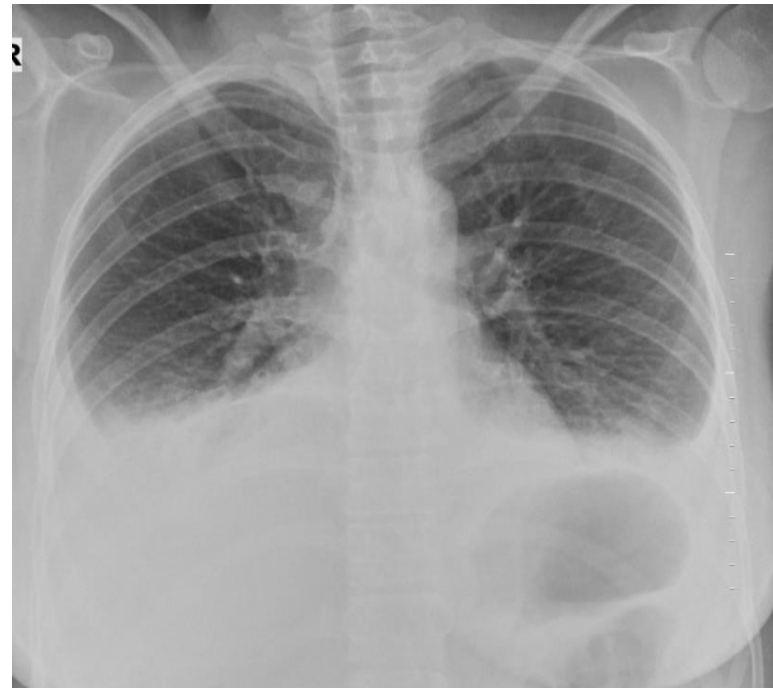

Figure 1: Chest radiograph at the time of admission

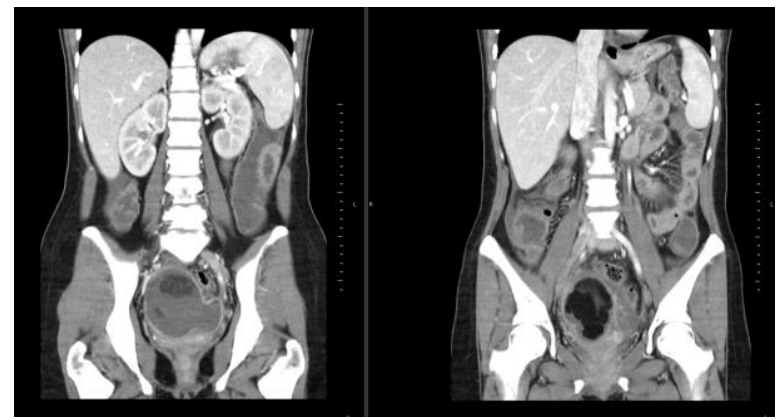

Figure 2: Preoperative abdominal computer tomography

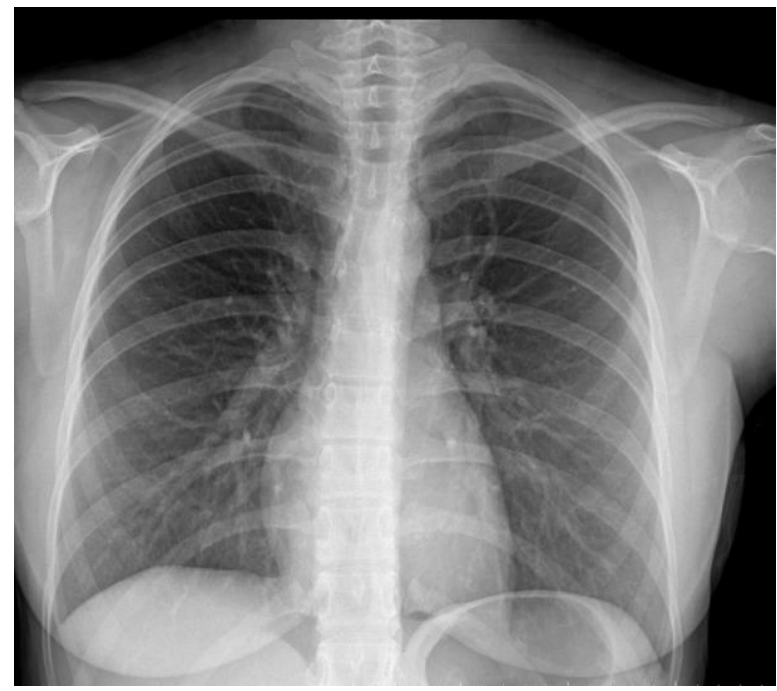

Figure 3: Two months after admission 
A cardiac examination revealed also a 2-centimeter pericardial effusion. No ascites were found in a novel abdominal ultrasonography.

The rapid occurrence of a post-operative pleural effusion led us to consider a reactional pleuropericardial effusion. A chest radiograph two days later showed a decreased left side pleural effusion. The patient was informed that the fluid would regress in a few weeks.

The patient was discharged the following day and prescribed antibiotics and anti-inflammatory drugs. One week later, she was re-admitted to the hospital with continuous side pain. A cardiac evaluation detected a regressed pericardial effusion with no tamponade finding. This time, to exclude a pulmonary embolism, she underwent a thorax CT angiography, revealing no thrombus. Excluding the other possible diagnoses, the patient was pre-diagnosed with non-classic Meigs-like syndrome. All symptoms were resolved two months later, and a chest radiograph showed complete regression (Figure 3).

Meigs' syndrome is a rare finding in coexistence with a benign ovarian tumor of fibroma, or a fibromalike tumor, ascites, pleural effusion and a curative resection of the tumor (2). A relationship with other benign ovarian tumors and other symptoms is defined as non-classic Meigs' syndrome (3).

Only a few studies examining the coexistence of pericardial effusion alongside Meigs' syndrome have been published to date, in which the condition is referred to as "Meigs-like syndrome". A postoperative increase in pleural effusion has been reported in only a single patient with an 8-year history of fibroma (4). In line with this case report, our case had pericardial effusion and ascites, and developed pleural effusion along with pericardial effusion after surgery.

A pleural effusion may occur just immediately after the operation, in which regressed ascites and pericardial effusion may have overflowed into the pleural cavity. We believe that our patient differs from those analyzed in literature in her acute presentation of a ruptured dermoid cyst. An accurate diagnosis of non-classic Meigs-like syndrome was accomplished 2 months after the operation, when the effusion had completely regressed.

This case report is important in revealing that the development of a pleural effusion following opera- tions on benign ruptured ovarian tumors is an encountered phenomenon. While pericardial effusion regresses rather early, the complete regression of a pleural effusion may take longer. Taking this syndrome into account, informing the patient and a close follow-up may allow needless investigations and examinations to be avoided.

\section{Fatma Tokgoz Akyil', Mustafa Akyıl ${ }^{2}$}

'Department of Chest Diseases, Çanakkale Mehmet Akif Ersoy State Hospital, Çanakkale, Turkey

${ }^{2}$ Department of Thoracic Surgery, Çanakkale Mehmet Akif Ersoy State Hospital, Çanakkale, Turkey

Correspondence (Illetişim): Fatma Tokgoz Akyil, Department of Chest Diseases, Çanakkale Mehmet Akif Ersoy State Hospital, Çanakkale, Turkey

e-mail: fatmatokgoz86@gmail.com

\section{CONFLICTS OF INTEREST}

None declared.

\section{AUTHOR CONTRIBUTIONS}

Concept - F.T.A., M.A.; Planning and Design F.T.A., M.A.; Supervision - F.T.A., M.A.; Funding -; Materials - F.T.A, M.A.; Data Collection and/or Processing - F.T.A., M.A.; Analysis and/or Interpretation - F.T.A.; Literature Review - F.T.A.; Writing F.T.A.; Critical Review - F.T.A., M.A.

\section{YAZAR KATKILARI}

Fikir - F.T.A., M.A.; Tasarım ve Dizayn - F.T.A., M.A.; Denetleme - F.T.A., M.A.; Kaynaklar -; Malzemeler F.T.A., M.A.; Veri Toplama ve/veya Işleme - F.T.A., M.A.; Analiz ve/veya Yorum - F.T.A.; Literatür Taraması - F.T.A.; Yazıyı Yazan - F.T.A.; Eleştirel İnceleme - F.T.A., M.A.

\section{REFERENCES}

1. Light RW, Macgregor MI, Luchsinger PC, Ball WC Jr. Pleural effusions: the diagnostic separation of transudates and exudates. Ann Intern Med 1972; 77:50713. [CrossRef]

2. Meigs JV. Fibroma of the ovary with ascites and hydrothorax - Meigs syndrome. Am J Obstet Gynecol 1954; 67:962-85. [CrossRef] 
3. Krenke R, Maskey-Warzechowska M, Korczynski P, Zielinska-Krawczyk M, Klimiuk J, Chazan R, Light RW. Pleural Effusion in Meigs' Syndrome-Transudate or Exudate?: Systematic Review of the Literature. Medicine 2015; 94:e2114. [CrossRef]
4. Okuda K, Nogochi S, Narumoto O, Ikemura M, Yamauchi $Y$, Tanaka G, et al. A case of Meigs' syndrome with preceding pericardial effusion in advance of pleural effusion. BMC Pulm Med 2016; 16:71. [CrossRef] 